\title{
PERBANDINGAN METODE CROPPING PADA SEBUAH CITRA UNTUK PENGAMBILAN MOTIF TERTENTU PADA KAIN SONGKET SUMATERA BARAT
}

\author{
Yuhandri \\ Fakultas Ilmu Komputer, Universitas Putra Indonesia YPTK, Indonesia \\ E-mail: yuyu@upiyptk.ac.id
}

\begin{abstract}
At the time of image processing where we only need a certain part of an image according to the needs called the Region of Interest (ROI), in order to obtain that, the processing is carried out in a cropping process. Cropping is mostly done by researchers, especially those who research in the field of image processing in order to do data processing on an image, the results of cropping process on an image are usually done to make it easier for researchers to focus on something that is needed only. In this study is to compare existing cropping methods to get a motif found in an image of West Sumatra songket fabric. In this study using the method of cropping rectangle, square, circle, ellipse, polygon and tested using the Matlab programming language. The results of comparison of 5 cropping methods for taking certain motifs on the songket image with 5 different songket image samples, shows that the best results are obtained by using the polygon method. Polygon method can reach certain coordinate points in a songket image, so that the results of cropping are better and other motives that are carried along during the cropping process can be reduced.
\end{abstract}

Keywords: Cropping, Songket, rectangle, square, circle, ellipse, polygon, Matlab

\begin{abstract}
Abstrak
Pada saat proses pengolahan citra dimana kita hanya membutuhkan bagian tertentu saja dari sebuah citra sesuai kebutuhan yang disebut dengan Region of Interest (ROI), guna mendapatkan itu maka dalam pemrosesan dilakukan sebuah proses cropping. Cropping banyak dilakukan oleh para peneliti terutama yang meneliti pada bidang image processing guna untuk melakukan pengolahan data pada sebuah citra, hasil proses cropping pada sebuah citra biasanya dilakukan untuk memudahkan peneliti fokus pada sesuatu obyek yang diperlukan saja. Pada penelitian ini adalah melakukan perbandingan metode cropping yang sudah ada untuk mendapatkan suatu motif yang terdapat pada sebuah citra kain songket Sumatera Barat. Pada penelitian ini menggunakan metode cropping rectangle, square, circle, ellipse, polygon dan diuji dengan menggunakan bahasa pemrograman Matlab. Hasil perbandingan 5 metode cropping untuk pengambilan motif tertentu pada citra songket dengan 5 sampel citra songket yang berbeda, menunjukan bahwa hasil terbaik diperoleh dengan meggunakan metode polygon. Metode polygon dapat menjangkau titik koordinat tertentu pada sebuah citra songket, sehingga hasil cropping lebih baik dan motif lain yang ikut terbawa pada saat proses cropping dapat dikurangi.
\end{abstract}

Kata kunci: Cropping, Songket, rectangle, square, circle, ellipse, polygon, Matlab 


\section{Pendahuluan}

Citra digital merupakan satu dari empat konten informasi dalam teknologi informasi multimedia yang terus berkembang saat ini. Citra digital telah banyak diaplikasikan dalam berbagai bidang, hal ini memperlihatkan bahwa pemahaman tentang teori pengolahan citra menjadi sangat penting [1]. Pada pengolahan citra kadangkala dibutuhkan objek tertentu pada sebuah citra yang besar untuk diambil dan dilakukan pengolahan, maka untuk mengatasi hal tersebut dibutuhkan suatu teknik tertentu guna mengambil objek yang diingini dalam sebuah citra. Teknik untuk mengambil objek tertentu dalam sebuah citra dikenal dengan istilah cropping image. Cropping image atau pemotongan area citra adalah teknik yang digunakan untuk menentukan secara tepat bagian mana dari citra tersebut yang mengandung area objek yang akan diolah (diingini), sehingga dapat dipotong dan dipisahkan dari area yang tidak dibutuhkan guna untuk pengolahan selanjutnya. Pemotongan bagian dari citra dapat dilakukan dengan mengunakan dua koordinat acuan, yaitu koordinat awal sudut kiri-atas sebagai awal koordinat bagi citra hasil pemotongan dan koordinat akhir sudut kanan-bawah yang merupakan titik koordinat akhir dari citra hasil pemotongan. Dari dua titik koordinat ini dapat dibentuk bangun segi empat sebagai ukuran citra baru hasil cropping yang didalamya terdapat semua objek yang akan diproses [2].

Proses pengambilan area tertentu pada sebuah citra (area of interest) disebut dengan pemotongan citra (cropping), dimana hasil dari proses pemotongan citra tersebut dapat digunakan untuk mempermudah dalam menganalisis sebuah citra. Umumnya pada proses pengolahan sebuah citra tidak semua atau tidak keseluruhan scene citra digunakan, oleh sebab itu guna mendapatkan area yang dibutuhkan tersebut maka dilakukan cropping. Hasil dari proses pemotongan citra tersebut dapat digunakan dalam kebutuhan data spasial dan data spektral. Titik koordinat, jumlah piksel dan hasil zooming daerah tertentu pada sebuah citra merupakan pedoman yang dapat digunakan dalam pemotongan sebuah citra [3].

\section{Tinjauan Literatur}

\subsection{Citra Digital}

Pengambilan citra yang didasarkan pada sampling dan kuantitasi dimana besar dan kecilnya piksel yang diperoleh berdasarkan dari besar dan kecilnya sampling serta besarnya nilai derajat keabuan dari kuantisasi disebut dengan citra digital. Pendefinisian sebuah citra digitial dapat menggunakan fungsi $(\mathrm{x}, \mathrm{y}), \mathrm{x}$ nomor baris dan y nilai kolom serta nilai derajat keabuan dengan $\mathrm{f}$. Posisi piksel dinyatakan dengan $(\mathrm{x}, \mathrm{y})$ dan nilai derajat keabuan dengan $\mathrm{f}$ pada titik $(\mathrm{x}, \mathrm{y})[4]$.

Pada saat sekarang sebuah citra atau gambar dapat dihasilkan dengan menggunakan teknologi yang lebih dikenal dengan sebutan pengolahan citra. Memanipulasi citra/gambar menjadi bentuk lain dengan menggunakan algoritma atau teknik-teknik tertentu disebut dengan pengolahan citra. Banyak manfaat yang didapat dengan pengolahan citra, dimana awalnya hanya berfungsi untuk 
memperbaiki kualitas sebuah citra dan terus berkembang menjadi pengolahan data yang sangat komplek, semua berkat perkembangan dari komputer yang semakin meningkat dalam pemrosessannya serta munculnya bidang computer vision. Istilah lain menyatakan bahwa pengolahan citra digital adalah pemrosesan gambar berdimensi dua melalui komputer digital [5]. Teknik untuk memanipulasi dan memodifikasi sebuah citra dengan berbagai cara juga disebut dengan istilah pengolahan citra [6].

Banyak hal penting pada sebuah pengolahan citra digital, seperti : proses filtering, threshold, histogram, sampling dan kuantisasi, model citra digital, teknik pengambilan citra, segmentasi, clustering dan ekstraksi ciri. Pada proses pengambilan citra dapat menggunakan alat seperti kamera digital [7], dimana dapat menghasilkan citra raster.

\subsection{Matlab}

Matlab adalah sebuah software yang dikembangkan oleh MathWorks, awal pembuatannya digunakan untuk memudahkan dalam mengakses data matriks pada proyek Linpack dan Eispack. Software Matlab sampai ini mengalami perkembangan yang pesat dimana saat ini sudah memiliki jumlah fungsi yang banyak sehingga dapat digunakan untuk mengatasi berbagai persoalan mulai dari masalah kecil sampai skala besar dari berbagai disiplin ilmu[8]. Software Matlab juga disebut sebagai bahasa dengan kinerja tinggi dalam mengatasi komputasi pada masalah-masalah teknik, dalam proses pemakaiannya Matlab sangat mudah untuk digunakan karena telah memadukan antara komputasi, visualisasi dan pemrograman kedalam satu model dimana penyelesaian masalah pada Matlab dalam bentuk notasi matematika [9].

Matlab mempunyai 5 susunan utama yang terdiri dari :

1. Development Environment: Terdiri dari kumpulan perangkat-perangkat dan fasilitas untuk memudahkan penggunaan fungsi dan file pada Matlab dalam bentuk Graphical User Interfaces (GUI), seperti dekstop, command history, editor, debugger, browsers, workspace, file dan search path.

2. Matlab Mathematical Function Library: Kumpulan berbagai macam algoritma komputasi yang terdiri dari fungsi-fungsi seperti, sum, sin, cos, dan complex arithmetic, matrix inverse, matrix eigenvalues, Bessel functions, dan fast Fourier transforms

3. Matlab Language: Pada Matlab terdapat high level matrix / array language dengan control flow statements, functions, data structures, input / output, dan fitur-fitur object oriented programming sehingga memungkinkan untuk dilakukan pemrograman baik dalam skala dan lingkup yang kecil sampai dengan skala dan lingkup yang sangat besar sehingga dapat memperoleh hasil yang sangat komplek.

4. Graphics: Dalam sebuah software pemrograman fasilitas graphichs adalah sebuah keharusan, begitu juga pada software Matlab ini juga dilengkapi dengan fasilitas untuk menampilkan vektor dan matriks dalam bentuk grafik. Terdapat fungsi-fungsi level tinggi guna visualisasi data dua dimensi maupun tiga dimensi, image processing, animation dan presentasi dalam bentuk grapfik.

5. Matlab Application Program Interface (API): Terdapat sebuah library pada software Matlab yang memungkinkan bahasa $\mathrm{C}$ dan Fortran dibaca pada Matlab. 


\subsection{Cropping Citra}

Pra-pengolahan terhadap data citra asli bertujuan untuk memperbaiki kualitas citra misalnya penghilangan noise yang terdapat di dalam citra, penajaman intensitas tepian objek dan penghilangan efek keburaman. Noise dapat diartikan sebagai informasi yang ikut terekam dalam citra namun informasi ini tidak dibutuhkan. Noise bisa saja berada di dalam area objek yang akan diteliti atau pun berada di luar area objek yang diteliti [10]. Khusus untuk noise yang berada di luar area objek yang diteliti, salah satu cara untuk menghilangkannya adalah dengan proses cropping. Memperkecil ukuran sebuah citra dengan cara memotong citra pada koordinat yang telah ditentukan pada suatu area pada citra disebut dengan istilah cropping [11]. Pada proses cropping akan diperoleh sebuah objek hasil pemotongan daripada sebuah citra atau bagian dari suatu gambar dengan ukuran tertentu.

Untuk proses cropping citra, perlu dilakukan lima langkah berikut :

1. Tentukan $\mathrm{x} 0$, y0: letak kursor di kiri atas area yang akan dipotong

2. Tentukan $x 1, y 1$ : letak baris di kiri atas area yang akan dipotong

3. Hitung delta $\mathrm{x}$ : lebar daerah yang akan dipotong

4. Hitung delta y: tinggi daerah yang akan dipotong

5. Hitung dua koordinat titik potong lainnya (sudut kiri-bawah dan kanan-atas)

Keempat properti yang ada pada langkah-langkah proses cropping citra dapat ditunjukkan pada Gambar 1 sedangkan Gambar 2 memperlihatkan contoh cropping citra. Terdapat ukuran 5x5 piksel pada citra asli, dilakukan cropping pada koordinat $(1,1)$ sampai koordinat $(3,3)$ dimana lebar 3 piksel dan tinggi 3 piksel sehingga menghasilkan citra baru berupa potongan dari citra asli dengan 3 x 3 piksel. Terdapat nilai koordinat $(1,1)$ sampai koordinat $(3,3)$ pada citra baru hasil cropping.

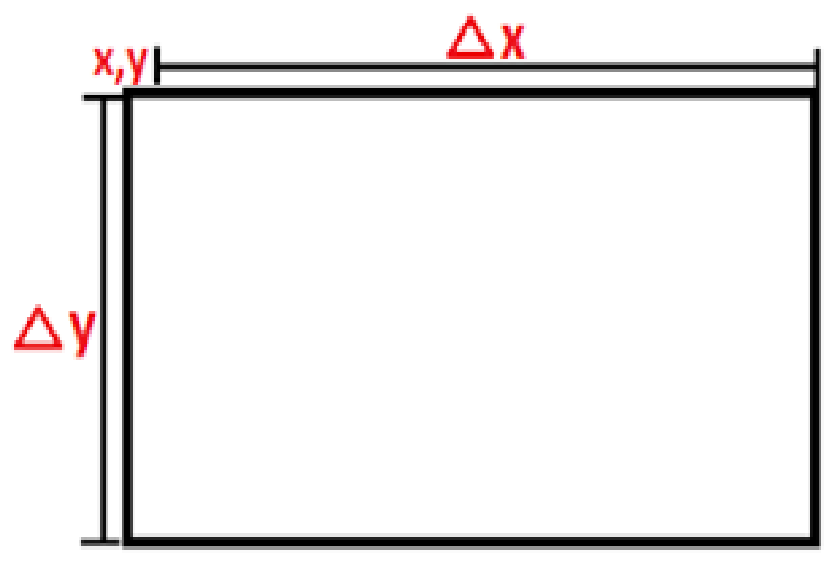

Gambar 1: Properti Area Untuk Cropping 


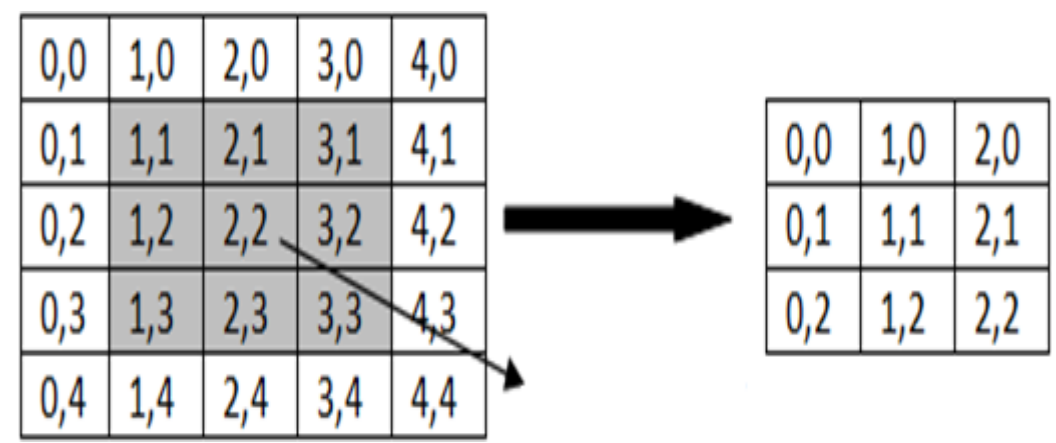

Gambar 2: Proses Pemotongan Citra

Dalam sejumlah bahasa pemrograman termasuk Bahasa Pemrograman Matlab lima langkah untuk proses cropping citra yang telah dijelaskan sebelumnya, sudah diimplementasikan dalam bentuk sebuah fungsi yang dapat langsung digunakan untuk melakukan cropping. Berikut beberapa metode yang digunakan dalam proses cropping pada sebuah image :

\section{Rectangle Crop}

Memotong citra secara rectangle lebih mudah untuk memangkas gambar karena dengan bentuk persegi panjang memudahkan untuk memilih dua koordinat pada citra tersebut [12]

\section{Square Crop}

Memotong gambar apa pun dalam bentuk persegi, terlebih dahulu harus menetapkan dua titik pada gambar untuk titik sudut dan kemudian menentukan titik dengan koordinat ini sehingga $\mathrm{x}=\mathrm{y}=\mathrm{d}$, di mana $\mathrm{d}$ adalah beberapa konstanta.

\section{Circle Crop}

Memilih pusat dari bentuk lingkaran di mana gambar akan dipotong, lalu memilih titik lain pada gambar untuk memutuskan radius gambar yang dipangkas. Dalam implementasi circle crop menggunakan locus of the circle untuk memotong gambar dalam bentuk lingkaran.

\section{Ellipse Crop}

Pada dua titik elips terdapat sebuah sumbu mayor, dimana titik-titik pada ujung sumbu mayor disebut puncak elips. Sementara garis berupa tegak lurus yang membagi sumbu mayor disebut dengan sumbu minor.

\section{Polygon Crop}

Bangunan dengan banyak segi tertentu disebut dengan Poligon, dimana dalam pemetaan menggunakan titik-titik dengan koordinat $\mathrm{X}$ dan $\mathrm{Y}$. 


\section{Metodologi}

Dalam melakukan sebuah penelitian haruslah menggunakan pendekatan-pendekatan ilmiah guna mendapatkan pengetahuan, dapat berupa cara, prosedur atau langkah-langkah dengan metode yang jelas serta tata cara yang objektif. Sehingga pada penelitian diperoleh hasil-hasil yang bersifat ilmiah dan bisa dipertanggung jawabkan [13]. Metode penelitian terbagi dalam dua tahap dengan skema dapat dilihat pada Gambar 3. Tahap pertama adalah pengumpulan citra songket yang digunakan untuk proses cropping. Tahap kedua adalah proses cropping dan hasil cropping.

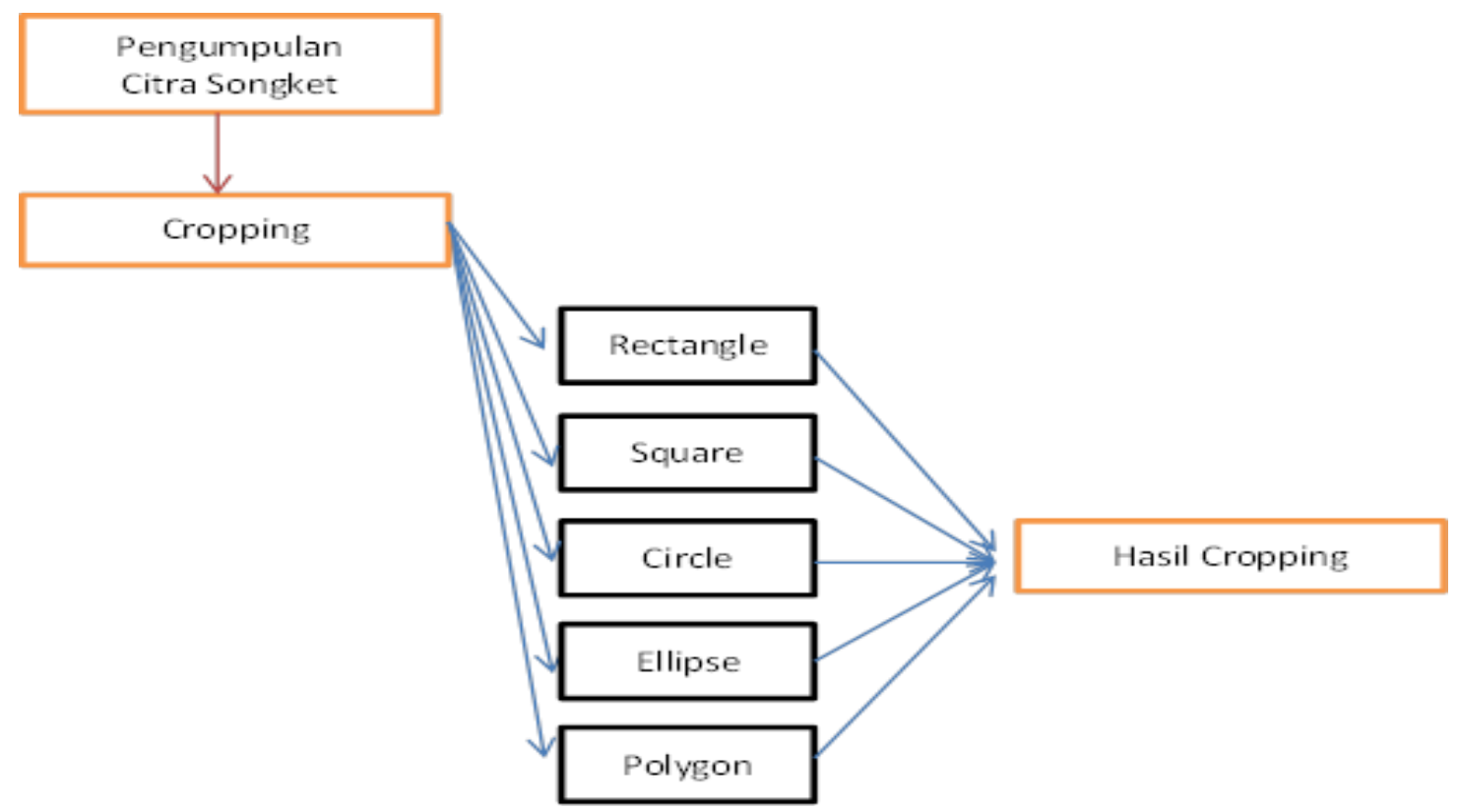

Gambar 3 : Bagan Alur Proses Penelitian

Penelitian ini dilakukan untuk membandingkan metode cropping yang ada dengan objek menggunakan citra kain songket Sumatera Barat dengan tujuan untuk mengetahui metode apa yang cocok diterapkan pada citra kain songket.

\section{Hasil dan Diskusi}

\subsection{Data Citra Songket}

Citra asli dijadikan sebagai data input. Citra yang digunakan adalah berupa citra songket dalam bentuk file dengan format *.jpg. Seluruh citra uji yang digunakan adalah citra songket berwarna dengan dimensi piksel yang mempunyai ukuran 1080 x 1350 piksel, yang tujuannya untuk menyeragamkan dimensi dari citra uji. Citra yang dikumpulkan adalah terdiri dari citra songket Pandai Sikek dan Silungkang sebanyak 5 citra. Citra songket yang digunakan dapat dilihat pada Tabel 1 dibawah ini [14]. 
Tabel 1: Citra Songket

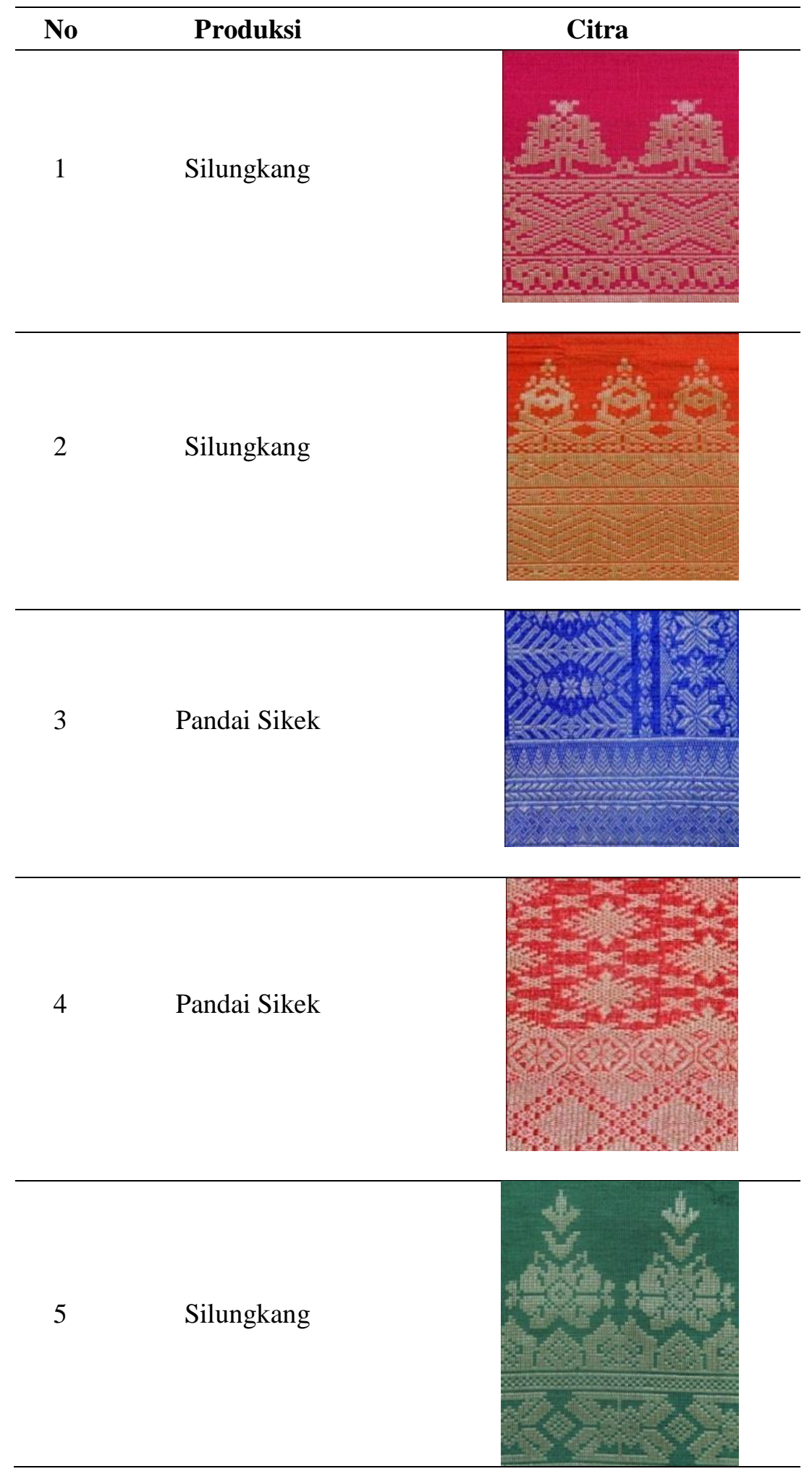

Jurnal KomtekInfo Vol : 6 No : 1|| 2019 


\subsection{Proses Cropping}

1. Cropping Menggunakan Rectangle Crop

image $=$ imread ('isi nama citra');

potong=imcrop(image,[isi koordinat])

imshow(image), figure imshow(potong)

\section{Cropping Menggunakan Square Crop}

image $=$ imread ('isi nama citra');

potong=imcrop(image,[isi koordinat])

imshow(image), figure imshow(potong)

\section{Cropping Menggunakan Circle Crop}

image $=$ imread ('isi nama citra');

potong=imcrop (image,[isi koordinat])

imshow(image), figure imshow(potong)

\section{Cropping Menggunakan Ellipse Crop}

image $=$ imread('isi nama citra')

potong $=$ imellipse $($ image, .........;

position = wait (potong);

imshow(image), figure imshow(potong)

\section{Cropping Menggunakan Polygon Crop}

image $=$ imread $($ 'isi nama

citra'); $\mathrm{c}=$ [isi koordinat];

$\mathrm{r}=$ [isi koordinat $]$;

$B W=$ roipoly (image, $c, r)$;

imshow(image), figure imshow(BW)

Jurnal KomtekInfo Vol : 6 No : $1 \| 2019$ 
Guna melihat perbandingan metode cropping ini maka dibuat pemrograman dengan Matlab, berikut Graphic User Interface (GUI) hasil perancangan sistem cropping :

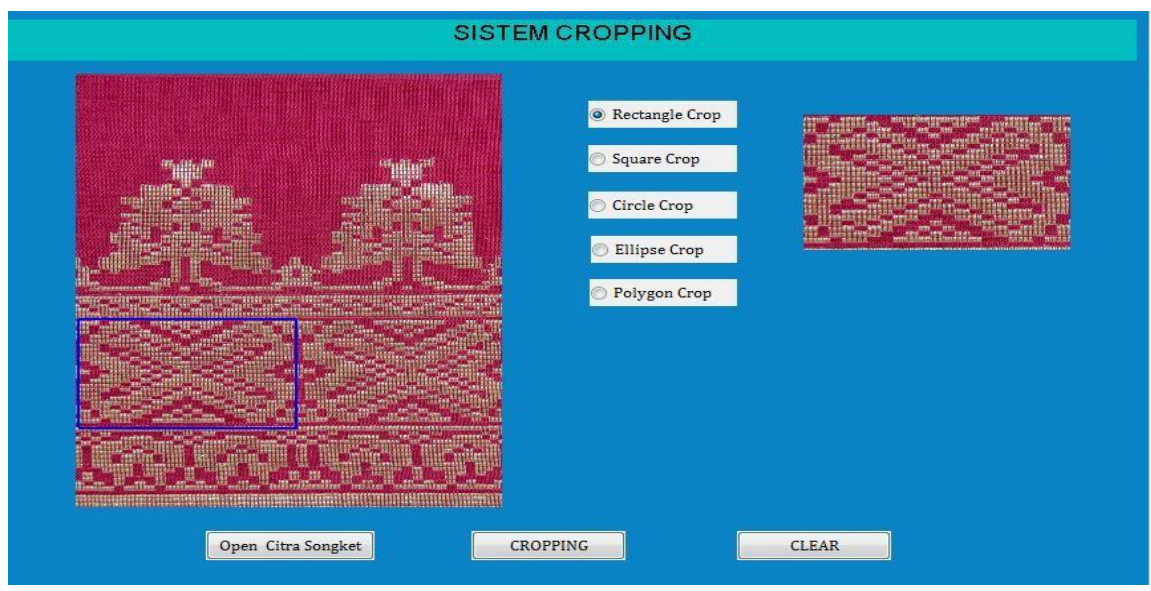

\section{Gambar 4: Menu Utama Sistem Cropping}

Pada menu utama sistem cropping dapat dilihat beberapa sub menu yaitu :

1. Open Citra Songket

Sub menu ini berguna untuk mengambil citra songket yang akan dilakukan cropping

\section{Cropping}

Setelah Citra dibuka maka selanjutnya dapat memili sub menu cropping

3. Rectangle, Square, Circle, Ellipse dan Polygon

Sub menu ini berfungsi untuk memilih metode cropping yang akan kita gunakan

Setelah melakukan uji coba terhadap 5 citra songket, maka diperoleh hasil seperti pada Tabel 5.

Tabel 5: Hasil Uji Coba Croping Citra Songket

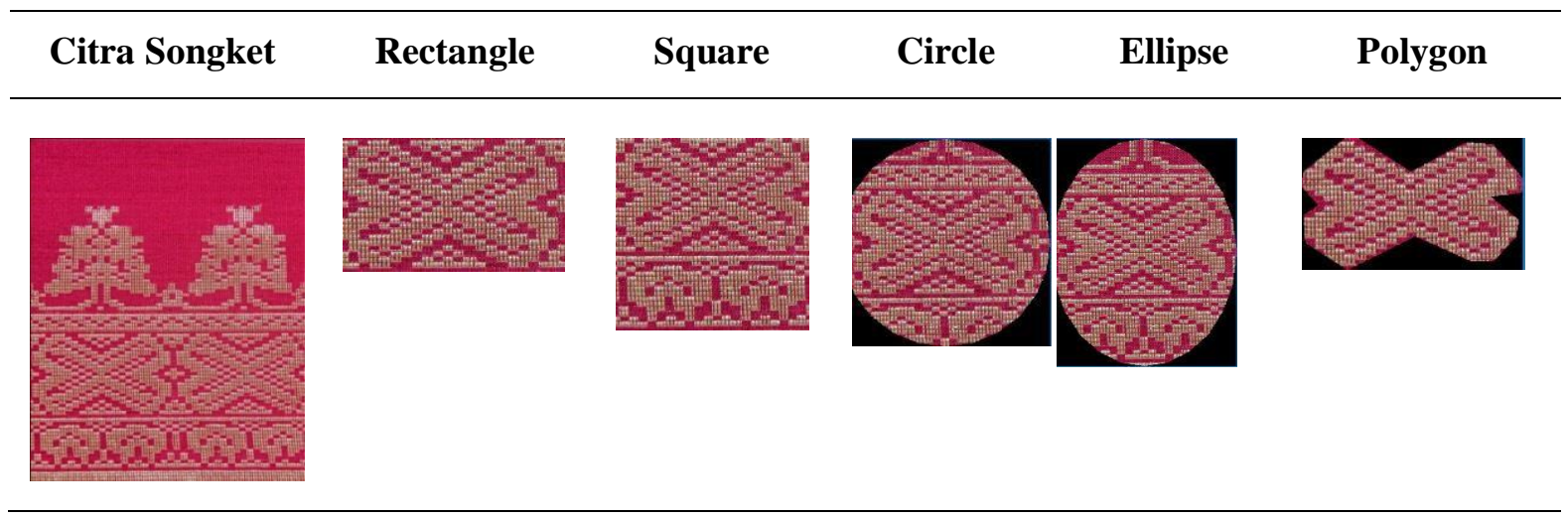




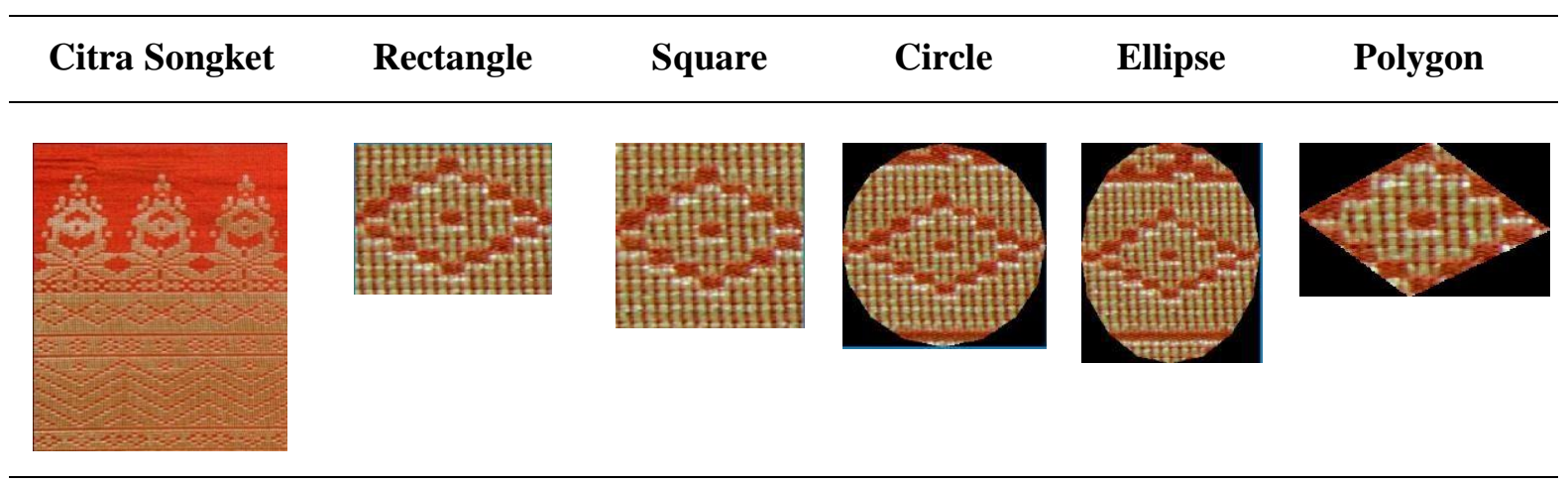
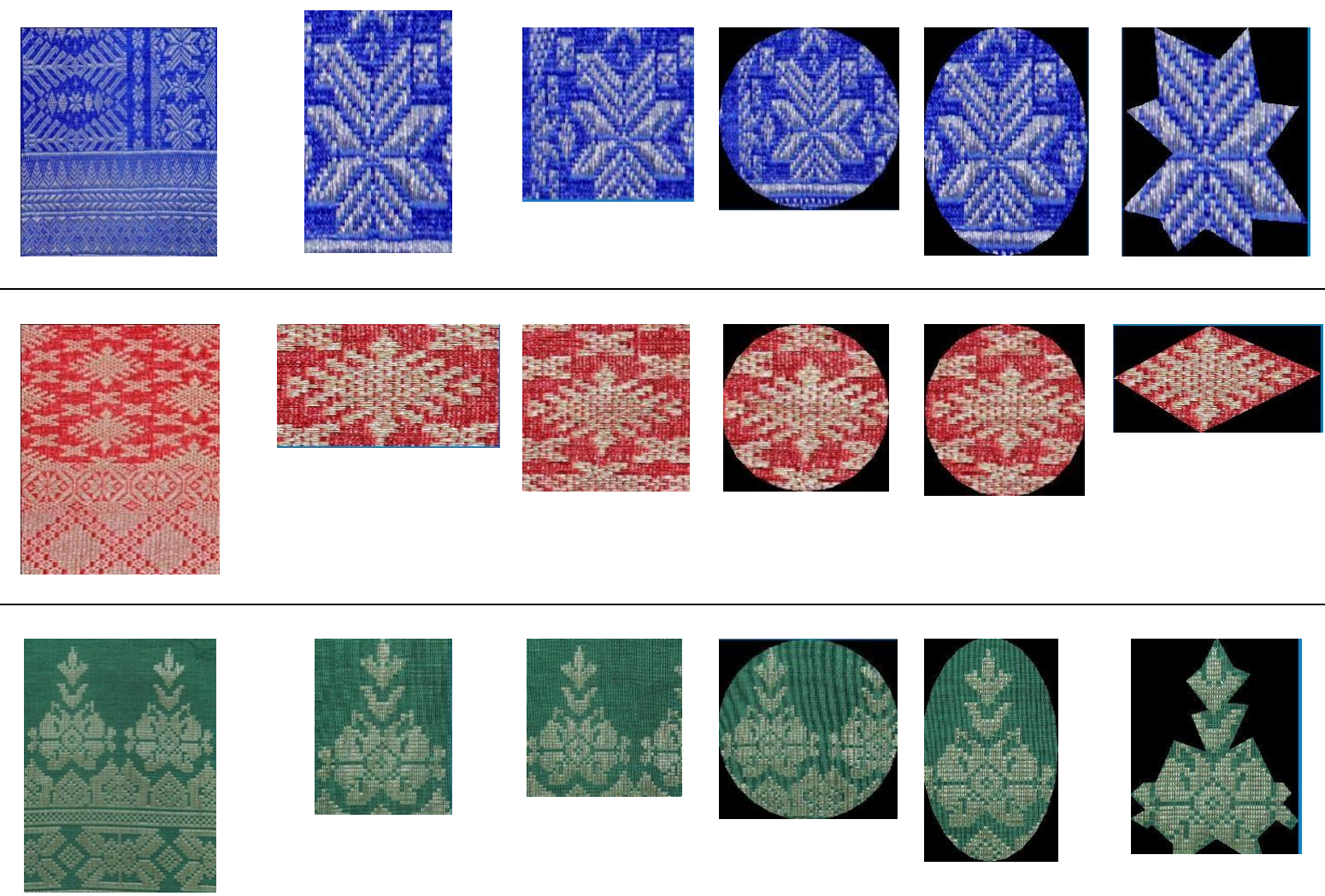

Pada Tabel 5 terlihat dengan jelas bahwa mengunakan rectangle crop, square crop, cirlce crop dan ellipse crop dalam pemotongan motifnya masih membawa motif disampingnya, sementara dengan polygon crop jauh lebih baik hasilnya dibanding dari yang lainnya, dengan demikian hasil penelitian ini menyimpulkan bahwa metode cropping yang cocok digunakan untuk citra songket dari Sumatera Barat ini adalah dengan polygon crop.

\section{Kesimpulan}

Pengambilan motif tertentu pada kain songket membutuhkan banyak titik koordinat karena motif songket mempunyai banyak lekukan dan tata letak yang rumit serta pada sebuah citra songket juga 
terdiri dari beberapa motif yang berbeda. Hasil perbandingan 5 metode cropping untuk pengambilan motif tertentu pada citra songket dengan 5 sampel citra songket yang berbeda, menunjukan bahwa hasil terbaik diperoleh dengan meggunakan metode polygon. Metode polygon dapat menjangkau titik koordinat tertentu pada sebuah citra songket, sehingga hasil cropping lebih baik dan motif lain yang ikut terbawa pada saat proses cropping dapat dikurangi.

\section{Referensi}

[1] Madenda S. (2015), "Pengolahan Citra Digital \& Video Digital, Teori Aplikasi, dan Pemrograman Menggunakan Matlab", Erlangga, Jakarta

[2] Santony J. (2014), "Segmentasi Citra X-Ray Thorax Penderita Tuberkulosis Berbasis Kulstering dengan Metode Fuzzy C-Means", Jurnal Komputer dan Teknologi Informasi (KomTekInfo) Fakultas Ilmu Komputer Universitas Putra Indonesia "YPTK" Padang, ISSN 2356-0010, Desember 2014, Hal. 40-43.

[3] Chen J., Bai G., Liang S. dan Li Z. (2016), "Automatic Image Cropping : A Computational Complexity Study", The IEEE Conference on Computer Vision and Pattern Recognition (CVPR) in Computer Vision Foundation (CVF), Las Vegas.

[4] Woods, Richard E., Gonzales, Rafael E. (2008), "Digital Image Processing Third Edition", Pearson Education. New Jersey.

[5] Anil K. Jain (1989),"'Fundamentals of Digital Image Processing", Prentice-Hall International

[6] Efford, N. (2000),"Digital Image Processing: A Practical Introduction Using Java", illustrated penyunt. the University of Michigan: Addison-Wesley

[7] Kadir A. dan Susanto A. (2013), "Pengolahan Citra, Teori Dan Aplikasi", Andi Publisher, Yogyakarta

[8] Firmansyah, A., (2007), “ Dasar-dasar Pemograman MATLAB”, IlmuKomputer.com. [diakses 21-12019]

[9] Iqbal, M., (2009), "Dasar Pengolahan Citra Menggunakan MATLAB”, Departmen Ilmu dan Teknologi Kelautan IPB.

[10] Kadir A., Nugroho L.E., Susanto A. dan Santosa P.I. (2011),"'Foliage Plant Retrieval Using Polar Fourier Transform, Color Moments and Vein Features. on Signal and Image Processing", An International Journal, Vol. 2, No. 3, Hal.1-13

[11] Saifullah S, Sunardi, Yudhana A (2016),"Analisis Perbandingan Pengolahan Citra Asli dan Hasil Croping Untuk Identifikasi Telur", Jurnal Teknik Informatika dan Sistem Informasi, Vol 2 No. 2, Hal. $341-350$

[12] Saluja N., Kumar A., Amisha, Khanna R., (2010),"Cropping Image In Rectangukar, Circular, Square and Triangular Form Using Matlab", National Conference on Computational Instrumentation CSIO Chandigarh, India, pp. 86-88

[13] Subiyanto, I., (1993),“Metodologi Penelitian”. Seri Diktat Kuliah, Gunadarma.

Jurnal KomtekInfo Vol : 6 No : $1 \| 2019$ 